\title{
Site Selection for an Earth Dam in Mbeere North, Embu County-Kenya
}

\author{
Fausta Mbura Njiru, David N. Siriba \\ Department of Geospatial and Space Technology, School of Engineering, University of Nairobi, Nairobi, Kenya \\ Email: faustanjiru@gmail.com
}

How to cite this paper: Njiru, F.M. and Siriba, D.N. (2018) Site Selection for an Earth Dam in Mbeere North, Embu County-Kenya. Journal of Geoscience and Environment Protection, 6, 113-133.

https://doi.org/10.4236/gep.2018.67009

Received: June 13, 2018

Accepted: July 28, 2018

Published: July 31, 2018

Copyright $\odot 2018$ by author and Scientific Research Publishing Inc. This work is licensed under the Creative Commons Attribution International License (CC BY 4.0).

http://creativecommons.org/licenses/by/4.0/

(c) (i) Open Access

\begin{abstract}
Choosing a suitable site for dam is a crucial phase in dam construction. A successful outcome of this effort is initiated by taking into consideration some watershed properties and characteristics. This study aimed to investigate hydrological information for dam site selection by integrating GIS with AHP Multi-Criteria Decision Analysis to establish hydrologic characteristics of the region suitable for a dam construction. The method used was based on consideration of seven criteria which included topographic factors (slope), geological factors, soil type, catchment size, land cover, proximity to river and proximity to roads. Data from ASTER GDEM was utilized for generating various topographic parameters while Geological Maps from Kenya Department of Mines were used for depicting rock formation/structure. Soil data from ILRI was used to show the distribution of the various soil categories. Land cover, roads and river centrelines were also used. This data was processed in ArcGIS to generate thematic layers of each criterion, on which weight was assigned depending on the most important factor. Weighted overlay analysis was applied to obtain layers showing suitable sites for dam construction. A final suitability map was established showing four possible sites of highly suitable areas for dam construction, with a capacity of 8.3 million $\mathrm{m}^{3}$ to North East, 14.9 million $\mathrm{m}^{3}$ to West, 26.9 million $\mathrm{m}^{3}$ to North West

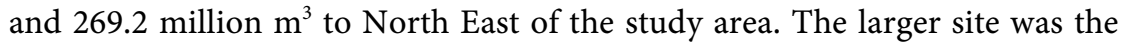
most recommended due to its narrow formation of contour troughs and ridges allowing for various dam options.
\end{abstract}

\section{Keywords}

Dam, Mbeere North, AHP, Weighted Overlay Analysis

\section{Introduction}

Constructing a dam is an important solution to curbing water problem for both 
domestic and irrigation purposes, which mostly occurs due to poor rainfall and prolonged dry seasons which lead to droughts. For this effort to be achieved successfully, it should be primarily centered on finding a suitable site for the dam. The main problem is to identify an effective, efficient and accurate method for dam site selection that will provide accurate terrain investigation and adequate information on the selected site for proper planning and design.

In this study, use of GIS and AHP Multi-Criteria Decision Analysis was preferred as a possible way of making optimal decisions in selecting a suitable site for dam construction. Major considerations involved GIS capabilities to acquire, store, retrieve, manipulate and analyze data while AHP Multi-Criteria Decision Analysis capabilities combined the geographic data with decision maker's preferences into alternative judgments [1].

Selecting a suitable site for an earth dam requires thorough consideration of several factors which include the watershed properties, such as slope, soil, geology, land cover and catchment, as well as social-economic factors, such as proximity to road and proximity to river among others [2]. Slope and the physical characteristics of the area are the most influential factors as they determine the inundation behaviour of the area under consideration [3]. Slope constitutes a major controlling factor on whether dam construction is essential to creating an appropriate habitat and at the same time, it dictates the river energy and velocity, hence closely connected with flood plain extent and river bank materials [4].

Remote sensing and GIS techniques application in hydrology are the utmost effective methodologies [5], which provides valuable datasets for examining hydrological variables and morphological changes for small, medium and large regions at different scales both spatial and temporal [3]. GIS significantly enhances the value of spatial analysis in land use administration as well as automatic delineation of drainage systems and fundamental catchments [6].

While GIS will provide layers dedicated for each factor in which weighting is done in AHP Multi-Criteria Decision Analysis, determination of suitable sites for dam construction is done using a weighted overlay process.

\section{Factors for Suitable Dam Site Location}

Different factors and corresponding criterion that were considered in the selection of a suitable site for dam construction are presented in Table 1. Each of the factors is described afterwards.

Topography is one of the major factors considered in the construction of earth dams with an appropriate reservoir [2]. Topography exerts a dominant control on flow routing through upstream catchment [7]. DTM, which provides a bare land representation of terrain or surface Topography [8], is very crucial for topographic characterization as it represents the ground surface, hydrological boundaries and terrain attributes which includes slope and aspect [9]. A well-drained, gently sloping site is preferable as it minimizes construction costs. Slope also influences the safety of dams since large degrees of slope has a higher 
Table 1. Selected criteria.

\begin{tabular}{|c|c|}
\hline Factor & Explanation based on experts opinion \\
\hline Slope (Topography) & The gentle the slope the better \\
\hline Geology & Stronger foundations are preferred for dam construction \\
\hline Soil type & The lower the soil infiltration rate, the better \\
\hline Land Cover & $\begin{array}{l}\text { Land cover prone to soil erosion are less conducive for dam } \\
\text { construction }\end{array}$ \\
\hline Proximity to Rivers & The nearer the dam to the river i.e. $\leq 1000 \mathrm{~m}$, the better \\
\hline Proximity to roads & The nearer the dam to the major roads buffer i.e. $\leq 1000 \mathrm{~m}$, the better \\
\hline Catchment size & $\begin{array}{l}\text { The bigger the catchment size, the more water it can provide for the } \\
\text { dam }\end{array}$ \\
\hline
\end{tabular}

risk of landslide and gives more pressure on foundations [10].

Geological foundation within a dam site often influences the type of dam suitable for that particular site [11]. Geological conditions not only regulate the character of formations, but also direct the available materials for dam construction [12]. Competent rock foundations have relatively high resistance to erosion, filtration and pressure, which includes igneous rocks such as granite among others [10]. One of the most important factors is a site with impermeable geological/dam foundation and without leakage, while it provides ease of construction as well as a guaranteed firm structure [13].

Soil type affects the volume of water that can infiltrate. Foundations of fine-grained soils which are water-resistant enough are recommended for a dam construction [11], which includes clay soils and their combinations [14].

The land cover of an area reflects the current use of the land and pattern as well as the importance of its use in relation to the population and its connection with the prevailing development [15]. Changes in land use and vegetation usually affect the water cycle and its influence is a function of the density of plant cover and morphology of plant species [16].

A suitable dam site should have a catchment area that is not so small such that the water is not sufficient enough to fill the dam, neither should it be so big such that it may require an expensive spillway [14]. This is guided by the catchment areas or the size of the drainage basin within the area.

The dam site should be easily accessible, so that it can be economically connected to the required population [17].

\subsection{Hydrological Modelling for Dam Site Selection}

GIS technology plays a useful role in all dimensions of drainage basin management, ranging from evaluating drainage basin characteristics all the way to modelling of human activities impacts [18]. Initial steps for hydrologic modelling in performing dam site selection comprises of delineation of streams and drainage basins, followed by determination of crucial watershed properties which includes 
slope, length of flow, density of stream network among others.

Assessing and managing water resources for dam site selection are essentially geographical activities which require handling of spatial data of different formats. Integration of various GIS and simulation models is essential to improve knowledge in water resource management for dams.

DEM has been commonly used for extraction of drainage patterns and other properties of a drainage basin required for hydrological modelling for dam selection. As described by [19], drainage network extraction and watershed delineation are algorithms which are developed from a DEM to derive basic topographic characteristics.

For dam site selection several Hydrological models are derived that collectively describes a catchment's drainage patterns. These include flow direction, flow accumulation, watersheds and stream networks among others. These functionalities forms the primary layers which are then integrated with other contributing factors in a GIS environment to derive suitable dam sites.

\subsection{Integration of GIS and AHP}

GIS alone doesn't have capabilities to include all decision elements related to land suitability assessment, even though it has power in spatial analysis. Instead it should be integrated with additional evaluation and assessment tools, like AHP Multi-Criteria Decision Analysis methods.

AHP Multi-Criteria Decision Analysis has functionalities and characteristics which makes it a suitable approach, as described by [20], and these characteristics includes the capability to tackle decision which involves subjective judgments, several decision makers and most importantly, the capability to offer consistency measures of preference. AHP Multi-Criteria Decision Analysis is described as a technique which is based on three principles of analysis: binary comparison; summarizing; prioritizing and selection [2]. Within GIS, it is applied to define the weights for the selected criteria, and has the ability to deal with inconsistent judgements.

The method is centred on the construction of a sequence of Pair-wise Comparison Matrices (PCMs), which all the criteria are compared to one another. For PCM elements, [21] suggested a scale of numbers 1 to 9. These numbers Indicates the number of times more or less important an element is over the other.

Calculation of weight estimate is then done, which is used for derivation of a consistency ratio (CR) of the pair-wise comparisons. As described by [22], PCM comprises of a consistency check in which judgment errors are identified and a consistency ratio is calculated. If CR is greater than 0.10 , then some pair-wise values requires some review and the procedure is repeated until the preferred value of CR of less than 0.10 is obtained.

Overlay analysis is then done in order to get the overall summation of the weight of each contributing factor. The overlay inputs includes all the contributing factor layers standardized to a common scale in a GIS environment. Each 
input raster is multiplied by the specified weight. It then adds all input rasters together to obtain the final suitability map.

\section{Materials and Methods}

\subsection{Study Area}

The study area is located in Mbeere North Sub-County and lies approximately between latitudes $0^{\circ} 25^{\prime}$ and $0^{\circ} 35^{\prime} \mathrm{S}$ and Longitudes $37^{\circ} 32^{\prime}$ and $37^{\circ} 50^{\prime} \mathrm{E}$ (see Figure 1). It covers approximately $514 \mathrm{~km}^{2}$ stretch along Ena River which intersects major segments of three Wards in Mbeere North Sub-County: Evurore, Nthawa and Muminji.

Mbeere North is mostly characterized by hot and dry semi-arid zones due to low annual rainfall of less than $600 \mathrm{~mm}$. Water shortage in the region has been a constraining factor limiting both crop production and livestock rearing hence leading to food insecurity.

According to [23], only 5\% of Embu County is under irrigation and there is great potential to expand irrigated area through water harvesting and storage in

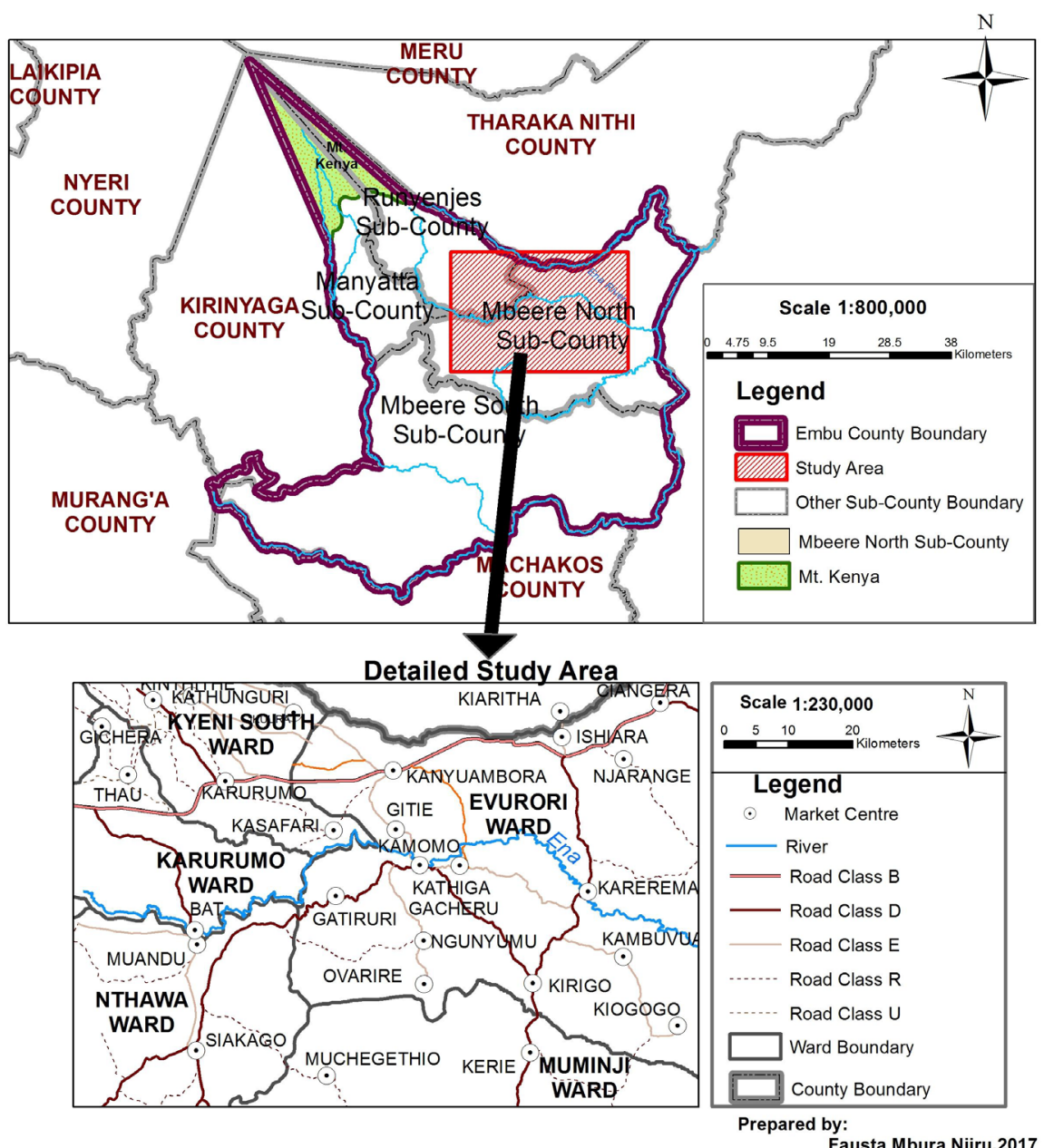

Figure 1. Study area. 
ponds pans and dams. The success of this effort is guided by finding a suitable site for the dam construction.

\subsection{Methodology}

The study used AHP Multi-Criteria Decision Analysis integrated in a GIS environment to determine suitable sites for an earth dam. The methodology was implemented in 4 phases. Phase one involved planning and other necessary logistics prior to project implementation. In phase two all necessary data was collected based on the number of criteria determined. Appropriate attributes for each criterion were established in phase three, and influence of each criterion was also determined using AHP Multi-Criteria Decision Analysis. In the final phase, the criteria organised as layers were combined by performing a weighted overlay analysis to produce a suitability map.

\subsection{Data Collection and Preparation}

This study involved use of various datasets. The data required was governed by a number of criteria that affect dam site selection which included Slope (Topography), Geology, Soil type, Catchment size, Land Cover, Proximity to River Centrelines and Proximity to roads.

The DEM data was obtained from the Advanced Space-borne Thermal Emission and Reflection Radiometer (ASTER) GDEM, with pixel size of 1 arc-second (approximately $30 \mathrm{~m}$ ). It was processed and used to generate elevation (DTM) and slope as indicated in Figure 2.

The processed DTM was used for delineation of watershed and generation of stream network according to the process flow in Figure 3.

The geology of the study area was obtained from Kenya Department of Mines and is dominated by granitoid gneisses, undifferentiated predominantly irregularly banded magmatic gneisses, kenyte lava, agglomerate and tuff rocks [24]. The permeability of gneisses and granite is originally very low but orogeny-related deep-seated fracture or shear zone in these rocks serves as good pass way or reservoir of ground water, therefore making the geology of the area suitable for dam construction [25] (see Figure 4).

The soil in the study area was obtained from ILRI GIS services website [26], consisting of four different classes i.e. Clayey, loamy, sandy and very clayey as illustrated in Figure 5.

The land cover data was sourced from Regional Centre for Mapping of Resources for Development (RCMRD). This data was already classified into six different types of land cover i.e. Dense Forest, Wooded Grassland, Open Grassland, Open Water, Perennial Cropland and Annual Cropland as illustrated in Figure 6.

The data for river and road centrelines is as shown in Figure 7. The dominant river across Embu County, Ena River was derived from the DTM while the road network was obtained from the topographical maps. 

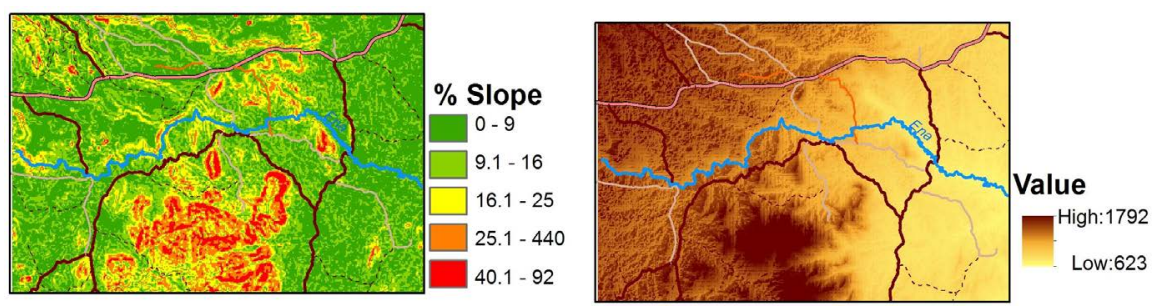

Figure 2. Slope and elevation (DTM).

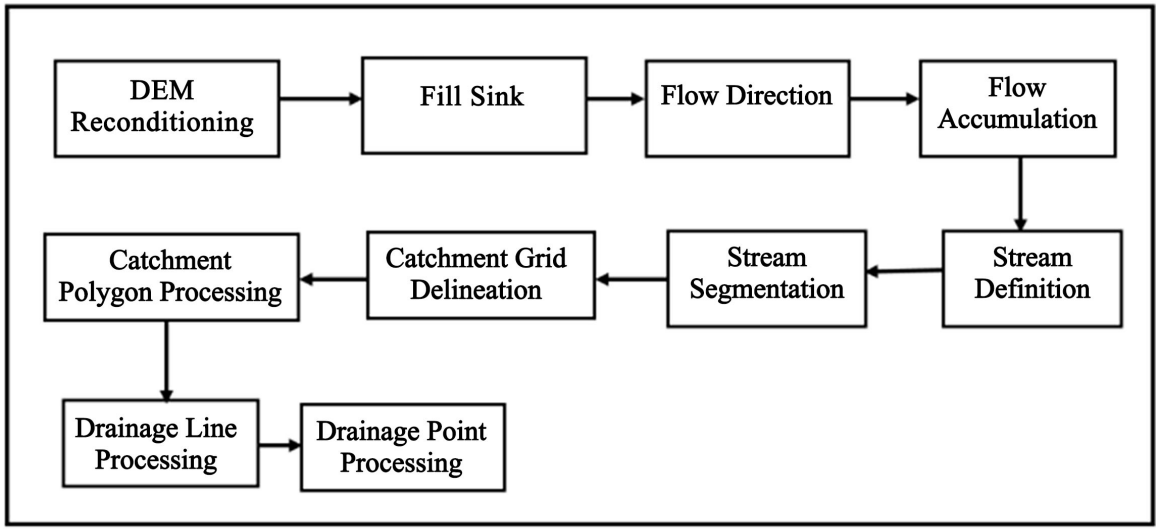

Figure 3. Terrain processing flow chart.
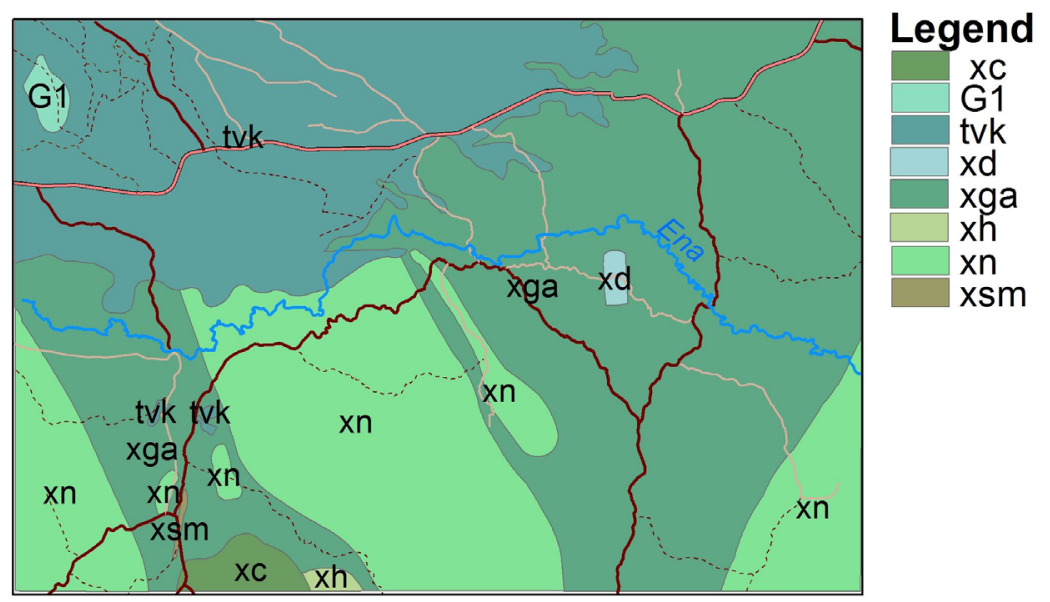

\begin{tabular}{|l|l|}
\hline Name & Explanation \\
\hline tvk & Kenyte lava, aggromerate \& tuff \\
\hline xn & Granitoid gneisses \\
\hline xd & Meta-dolerites \\
\hline xga & Undifferenciated, predominantly irregularly banded gneisses \\
\hline xc & Meta-calcareous granulites \\
\hline xh & Hornblend biotite gneiss \\
\hline xsm & Muscovite paragneisses \& schists \\
\hline tvk & Kenyte lava, aggromerate \& tuff \\
\hline G1 & Granitoid para-and ortho gneisses \\
\hline
\end{tabular}

Figure 4. Geology map. 


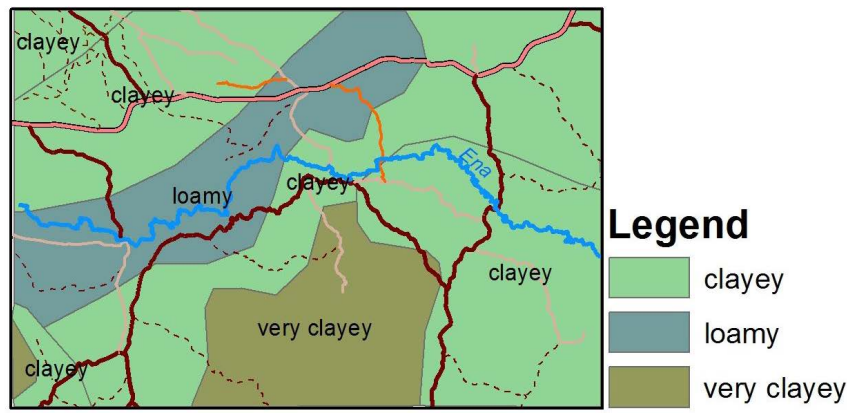

Figure 5. Soil map.

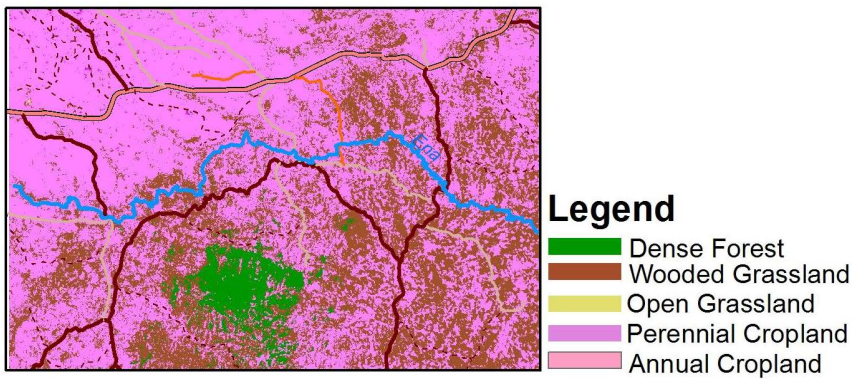

Figure 6. Land cover map.

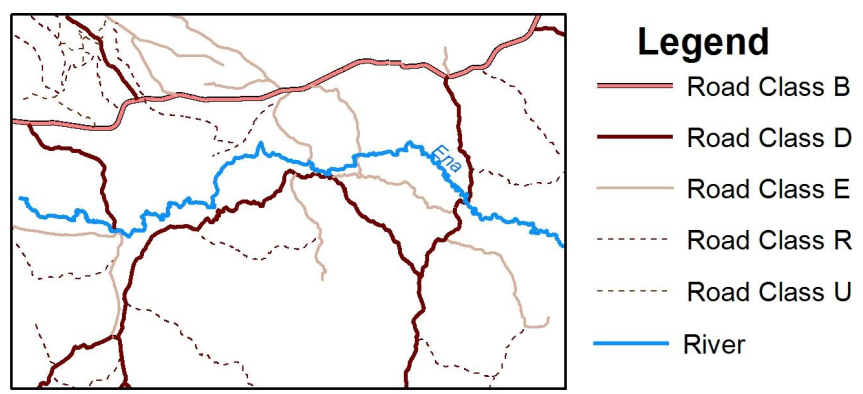

Figure 7. Road and river centreline.

\subsection{Weighting of Factors Using AHP Multi-Criteria Decision Analysis}

Each factor was assigned a weight which indicated their significance. In this study AHP pair-wise comparison method was used.

Several online programs are available for calculating AHP priority weights which includes Microsoft Excel, BPMSG AHP Online System [27] among others. The program used for this study was Microsoft Excel as described by [28].

The analysis utilizes seven different map layers as inputs in the suitability; Slope, Geology, Soil type, Catchment size, Land Cover, Proximity to river and roads. Each of these was converted into raster format.

The problem was decomposed into a level of hierarchy consisting crucial elements of the decision problem. The first layer indicates the goal of decisions making, the second layer containing the criterion to be used and the third level showing the decisions making attributes as shown in Figure 8. 


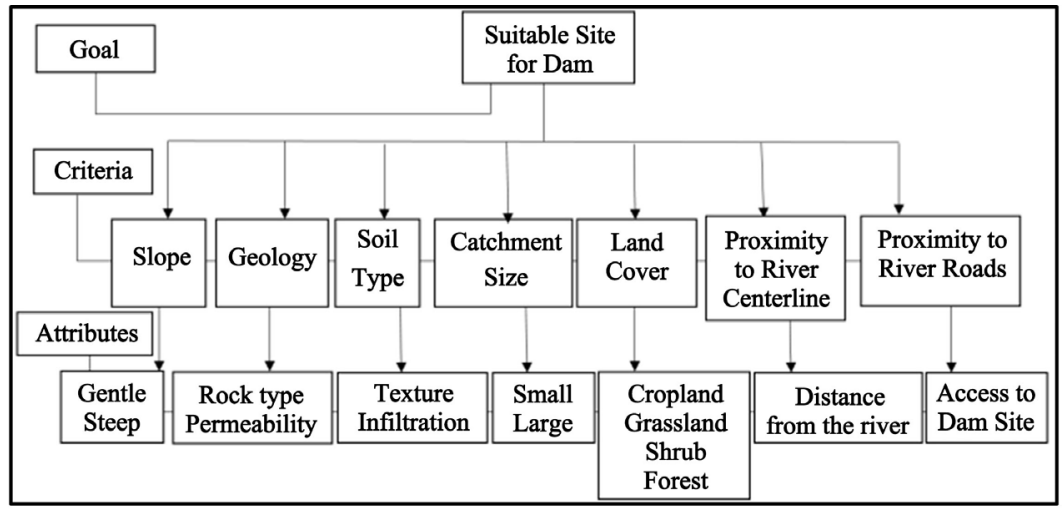

Figure 8. Three stage MCDA (goal, criteria and attributes).

An assessment of the relative importance of each criterion with one another within a scale of 1 to 9 was used. This allows for the equitable comparison of intensities of suitability, with 1 being factors of equal preference and 9 being the factors with extreme preference over the other as shown in Table 2. In this process, the main assumption is that if first factor has one of the above non-zero numbers assigned to it when compared with the second factor, then the second factor is assigned the reciprocal of the first e.g. if slope compared to land cover has a factor of 9 , then the land cover will have a factor of $1 / 9$.

From previous studies on dam site selection, incorporated with the experts' opinion on factors affecting dam site selection, the order of importance of each criterion is as indicated in Table 3.

To determine the weight of each factor, Pair-wise Comparison was used as illustrated in Table 4. A matrix was constructed in which relative to its importance, a criterion was compared with the other on a scale of 1 to 9 .

The total was the summation of each column:

$$
\begin{aligned}
& \text { Slope }=1+\frac{1}{2}+\frac{1}{5}+\frac{1}{3}+\frac{1}{7}+\frac{1}{9}=2 \frac{2}{5} \\
& \text { Geology }=2+1+\frac{1}{2}+\frac{1}{7}+\frac{1}{9}+\frac{1}{9}=4 \\
& \text { Soil type }=5+2+1+\frac{1}{2}+\frac{1}{3}+\frac{1}{7}+\frac{1}{5}=9 \frac{1}{6} \\
& \text { Catchment Size }=3+7+2+1+\frac{1}{3}+\frac{1}{5}+\frac{1}{5}=13 \frac{3}{4} \\
& \text { Land Cover }=7+7+3+3+1+\frac{1}{2}+\frac{1}{2}=22 \\
& \text { Proximity to River }=9+9+5+5+2+1+\frac{1}{2}=31 \frac{1}{2} \\
& \text { Proximity to Roads }=9+9+7+5+2+2+1=35
\end{aligned}
$$

while the intensity of importance is allocated to criterion $i$ when compared to criterion $j$, the reciprocal value is assigned to criterion $j$ as intensity of importance. For example, from the above matrix, $i$ (slope) $=9$ while $j$ (Proximity to Road $)=1 / 9$. After comparison between all possible criteria pairs is complete, the 
Weight $(W)$ of criteria $i$ is calculated using Equation (1). See Table 5 for the calculated weight $(W)$.

$$
W_{i}=\sum_{j=1}^{n} P i j /\left(\sum_{i=1}^{n} \sum_{j=1}^{n} P i j\right)
$$

Equation (1): Calculation of weight (source (Dai, 2016)) where:

$P i j=$ Relative importance in pair-wise comparison of criterion $i$ compared to criterion $j$

$n=$ Number of factors

$i \& j=$ Criterion

$W=$ Priority Weight

The values used for pair-wise comparison usually rely on subjective judgement which could lead to arbitrary results with bias. To evaluate the consistency of pair-wise comparison matrix, a numerical index called Consistent Ratio $(C R)$ is used as indicated in Equation (2) below. CR shows the ratio of the Consistency Index $(C I)$ to the average consistency index, known as Radom Index $(R I)$ as shown in equation 3.

$$
C R=\frac{C I}{R I}
$$

Equation (2): Calculation of Consistency Ratio

The calculation of $C I$ is given as:

$$
C I=\left(\lambda_{\max }-n\right) / n-1
$$

Equation (3): Calculation of Consistency Index where:

$n$ is the number of factors $=7$

$\lambda_{\max }$ is the Principal Eigen Value

$\lambda_{\max }=\Sigma$ of the products between each element of the priority vector and column totals

$$
\begin{aligned}
& \lambda_{\max }=(22 / 5 \times 0.3629)+(4 \times 0.2924)+(91 / 6 \times 0.1368)+(133 / 4 \times 0.1057)+ \\
& (22 \times 0.0460)+(311 / 2 \times 0.0308)+(35 \times 0.0254)=7.6201 \\
& \mathrm{CI}=(7.6201-7) / 7-1 \\
& =0.6201 / 6 \\
& =0.1033
\end{aligned}
$$

The $R I$ used depends on the number of criteria. This study has seven criteria hence the RI used was 1.32 as indicated in Table 6.

$$
\begin{aligned}
& C R=C I / R I \\
& C R=0.1033 / 1.32 \\
& =0.07
\end{aligned}
$$

According to [31], the value of $C R$ is compared to 0.1 which is the maximum $C R$ value for an acceptable pair-wise comparison. The resulting $C R$ for this analysis is 0.07 which is less than the acceptable maximum $C R$ value recommended in AHP and therefore this consistency is acceptable. 
Table 2. Intensity of importance.

\begin{tabular}{|c|c|c|}
\hline $\begin{array}{l}\text { Intensity of } \\
\text { Importance }\end{array}$ & Definition & Explanation \\
\hline 1 & Equal Importance & $\begin{array}{l}\text { Two activities contribute equally to the } \\
\text { objective }\end{array}$ \\
\hline 2 & Weak or slight & \\
\hline 3 & Moderate importance & $\begin{array}{l}\text { The judgment slightly } \\
\text { favour one activity over } \\
\text { another }\end{array}$ \\
\hline 4 & Moderate plus & \\
\hline 5 & Strong importance & $\begin{array}{l}\text { The judgment strongly } \\
\text { favour one activity over } \\
\text { another }\end{array}$ \\
\hline 6 & Strong plus & \\
\hline 7 & Very strong & $\begin{array}{c}\text { An activity is favoured very strongly over } \\
\text { another }\end{array}$ \\
\hline 8 & Very, very strong & \\
\hline 9 & Extreme importance & $\begin{array}{c}\text { The evidence favouring one activity over } \\
\text { another is of the highest possible order of } \\
\text { weight }\end{array}$ \\
\hline
\end{tabular}

Table 3. Order of importance.

\begin{tabular}{|c|c|c|}
\hline Factor & $\begin{array}{l}\text { Order of } \\
\text { Importance }\end{array}$ & Argument \\
\hline Slope & 1 & $\begin{array}{l}\text { Slope influences dam safety since higher slopes have more risks of } \\
\text { landslides and usually give pressure to the foundation of the dam } \\
\text { [10] }\end{array}$ \\
\hline Geology & 2 & $\begin{array}{l}\text { The rock type within a certain region influences permeability of } \\
\text { the dam [25] which includes the capability of holding water for } \\
\text { the dam }\end{array}$ \\
\hline Soil type & 3 & $\begin{array}{l}\text { Different soil types have different infiltration rate which usually } \\
\text { influence the runoff flowing to the dam [29] }\end{array}$ \\
\hline Catchment Size & 4 & A Large catchment will provide sufficient water for the dam [30] \\
\hline Land Cover & 5 & $\begin{array}{l}\text { This is useful for examination of land that have different } \\
\text { economical cost depending on the land cover type and at the } \\
\text { same time land cover influences soil erosion which usually } \\
\text { creates a weak foundation for constructing a dam [10] }\end{array}$ \\
\hline $\begin{array}{l}\text { Proximity } \\
\text { to River }\end{array}$ & 6 & $\begin{array}{l}\text { A suitable dam site should be within a buffer of one kilometre } \\
\text { from the river. This was considered an economically sustainable } \\
\text { distance from the river (Experts opinion) }\end{array}$ \\
\hline $\begin{array}{l}\text { Proximity } \\
\text { to Roads }\end{array}$ & 7 & $\begin{array}{l}\text { The dam site should be easily accessible, so that it can be } \\
\text { economically connected to the required population [17] }\end{array}$ \\
\hline
\end{tabular}


Table 4. Pair-wise comparison.

\begin{tabular}{cccccccc}
\hline Factors & Slope & Geology & Soil type & $\begin{array}{c}\text { Catchment } \\
\text { Size }\end{array}$ & $\begin{array}{c}\text { Land } \\
\text { Cover }\end{array}$ & $\begin{array}{c}\text { Proximity Proximity } \\
\text { to Rivers }\end{array}$ \\
to Roads
\end{tabular}

Table 5. Weight determination.

\begin{tabular}{cccccccccc}
\hline Factors & Slope & Geology & $\begin{array}{c}\text { Soil } \\
\text { type }\end{array}$ & $\begin{array}{c}\text { Catchment } \\
\text { Size }\end{array}$ & $\begin{array}{c}\text { Land } \\
\text { Cover }\end{array}$ & $\begin{array}{c}\text { ProximityProximity } \\
\text { to River }\end{array}$ & $\begin{array}{c}\text { Priority } \\
\text { to Road } \\
\text { (W) }\end{array}$ \\
\hline Slope & 0.42 & 0.49 & 0.55 & 0.22 & 0.32 & 0.29 & 0.26 & 0.37 \\
Geology & 0.21 & 0.25 & 0.29 & 0.51 & 0.32 & 0.29 & 0.26 & 0.29 \\
Soil type & 0.08 & 0.12 & 0.11 & 0.15 & 0.14 & 0.16 & 0.20 & 0.17 \\
Catchment Size & 0.14 & 0.04 & 0.05 & 0.07 & 0.14 & 0.16 & 0.14 & 0.11 \\
Land Cover & 0.06 & 0.04 & 0.04 & 0.02 & 0.05 & 0.06 & 0.06 & 0.05 \\
Proximity to River & 0.05 & 0.03 & 0.02 & 0.01 & 0.02 & 0.03 & 0.06 & 0.03 \\
$\begin{array}{c}\text { Proximity to } \\
\text { Roads }\end{array}$ & 0.05 & 0.03 & 0.02 & 0.02 & 0.02 & 0.02 & 0.03 & 0.03 \\
Total & 1.00 & 1.00 & 1.00 & 1.00 & 1.00 & 1.00 & 1.00 & 1.00 \\
\hline
\end{tabular}

Table 6. Random index values.

\begin{tabular}{ccccccccccc}
\hline $\mathrm{n}$ & 1 & 2 & 3 & 4 & 5 & 6 & 7 & 8 & 9 & 10 \\
\hline $\mathrm{RI}$ & 0 & 0 & 0.58 & 0.90 & 1.12 & 1.24 & 1.32 & 1.41 & 1.45 & 1.49 \\
\hline
\end{tabular}

Source: [31].

\subsection{Standardization}

Values must be prioritized even within a single raster. This is because values in a particular raster may be fit for your purpose while others may be undesirable [32]. For example a slope of $0 \%-9 \%$ is ideal for dam site selection. This was done through a process of reclassification in ArcGIS.

To perform the reclassification, each raster dataset was reclassified into a common scale of 1 to 5 . With 5 being more favourable hence has the highest influence for dam site selection and 1 with the lowest influence. 
Classification of geological factors mainly depended on the permeability, thickness and strength of rocks foundations at the area of interest [33]. Stronger foundation was given the highest scale of 5 while weaker was given the lowest scale of 1 .

Dam site construction requires topography that is well-drained and gently sloping. This is best as it minimizes construction costs as described by [34]. Gentle slope was given the highest scale of 5 steep slope was given the lowest scale of 1 .

The choice of the dam site should provide a large area for water storage and this is determined by the size of the water catchment areas around the selected area. Catchment size determines what water is available within a catchment [30]. A large catchment was given the highest scale of 5 while a small catchment was given the lowest scale of 1 .

According to [35], the land covered by plant biomass is more resistant to both wind and water soil erosion and therefore usually experience moderately little erosion. In this regard, Wooded Grassland was given a highest scale of 5 .

The ranking of soil was done based on the soil infiltration rate. As described by [29], the smaller the soil particles, the slower the water infiltration rate. To ensure minimum loss of water through seepage soils must be impermeable, with more than $20 \%$ clay [34]. Therefore clayey soil was given the highest scale of 5 and the sandy soil was given the lowest scale of 1 .

The closer the dam to the river, the better for economical purposes. The closest distance of $500 \mathrm{~m}$ buffer from the river centreline was given the highest scale of 5 while distances beyond 3 kilometres were given a lower scale of 1 .

The near the dam to transport networks, the better the accessibility [2]. Therefore short distances were given the highest scale of 5 and longer distances were given the lowers scale of 1 . Tables $7(\mathrm{a})$-(g) show the corresponding standardized layers.

\section{Results}

The overlay inputs were all the layers standardized into a common scale of 1 to 5, with 5 being the most favourable as shown in Figure 9. By using the Weighted Sum tool in ArcGIS, each input raster is multiplied by the specified weight. It then overlays all input raster layers together to obtain the final suitability map (Figure 10).

The map was reclassified into five suitability classes. A bar graph showing area in kilometres and percentages for various suitability levels was also produced (Figure 11).

As the map shows, the northern area towards Mt. Kenya highlands is showing mixed levels of low suitability. This is probably because of changes in slope as steep slopes are dominant as we approach Mt. Kenya. Suitability increases as we move towards the interior of Mbeere North Sub-County. This is probably favoured by flat slopes within the area. 
Table 7. (a) Summary of ranking for slope; (b) Summary of ranking for Geology; (c) Summary of ranking for Soil; (d) Summary of ranking for Catchment; (e) Summary of ranking for Land cover; (f) Summary of ranking for Rivers; (g) Summary of ranking for Roads.

(a)

\begin{tabular}{cc}
\hline Slope (\%) & Rank \\
\hline $0-9$ & 5 \\
$9.1-16$ & 4 \\
$16.1-25$ & 3 \\
$25.1-40$ & 2 \\
$40.1-92$ & 1 \\
\hline
\end{tabular}

(b)

\begin{tabular}{cc}
\hline Geology (Rock type) & Rank \\
\hline irregularly banded migmatitic gneiss & 5 \\
Kenyte lava, aggiomerate and tuff & 4 \\
Granitoid gneiss & 3 \\
\hline
\end{tabular}

(c)

\begin{tabular}{cc}
\hline Soil type & Rank \\
\hline Very Clayey & 5 \\
Clayey & 4 \\
Loamy & 3 \\
Sandy & 2 \\
Very Sandy & 1 \\
\hline
\end{tabular}

(d)

\begin{tabular}{cc}
\hline Catchment Size (km sq.) & Rank \\
\hline $1.87-2.11$ & 5 \\
$1.03-1.86$ & 4 \\
$0.726-1.02$ & 3 \\
$0.451-0.725$ & 2 \\
$0.02-0.45$ & 1 \\
\hline
\end{tabular}

(e)

\begin{tabular}{cc}
\hline Land Cover & Rank \\
\hline Wooded Grassland & 5 \\
Open Grassland & 4 \\
Annual Cropland & 3 \\
Perennial Cropland & 2 \\
Forested area & 1 \\
\hline
\end{tabular}


(f)

\begin{tabular}{cc}
\hline Proximity to River $(\mathrm{km})$ & Rank \\
\hline $0-0.5$ & 5 \\
$0.5-1.0$ & 4 \\
$1.1-1.5$ & 3 \\
$1.51-2.0$ & 2 \\
2.01 and above & 1 \\
\hline
\end{tabular}

(g)

\begin{tabular}{cc}
\hline Proximity to Roads $(\mathrm{km})$ & Rank \\
\hline $0-1.0$ & 5 \\
$1.1-2.0$ & 4 \\
$2.1-3.0$ & 3 \\
$3.1-4.0$ & 2 \\
4.1 and above & 1 \\
\hline
\end{tabular}
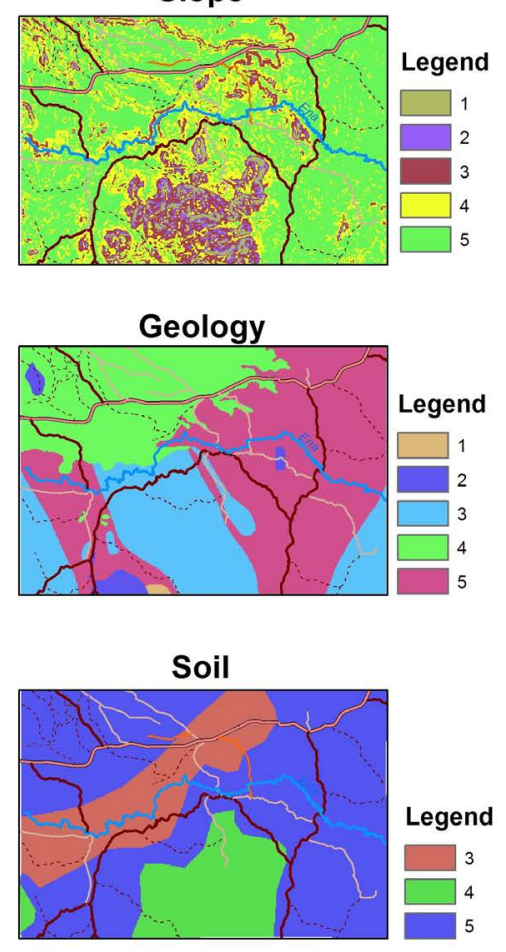

\section{Catchment}

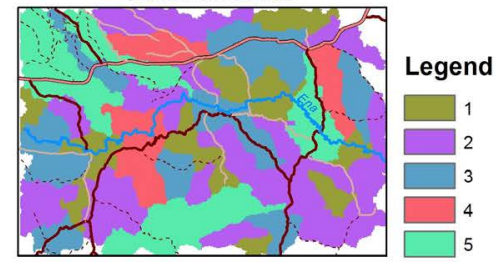

Figure 9. Standardized layers.
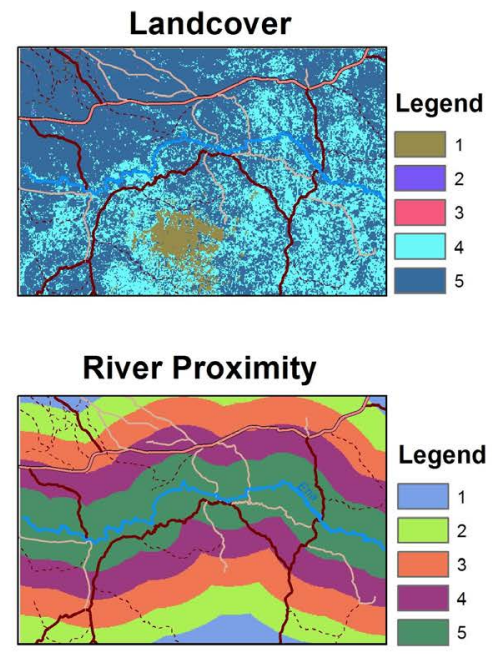

Road Proximity

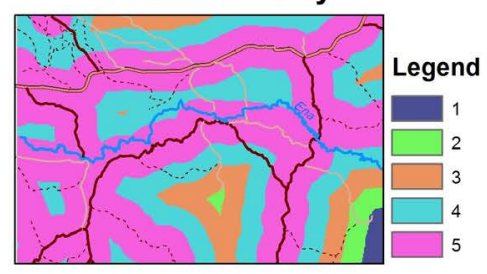




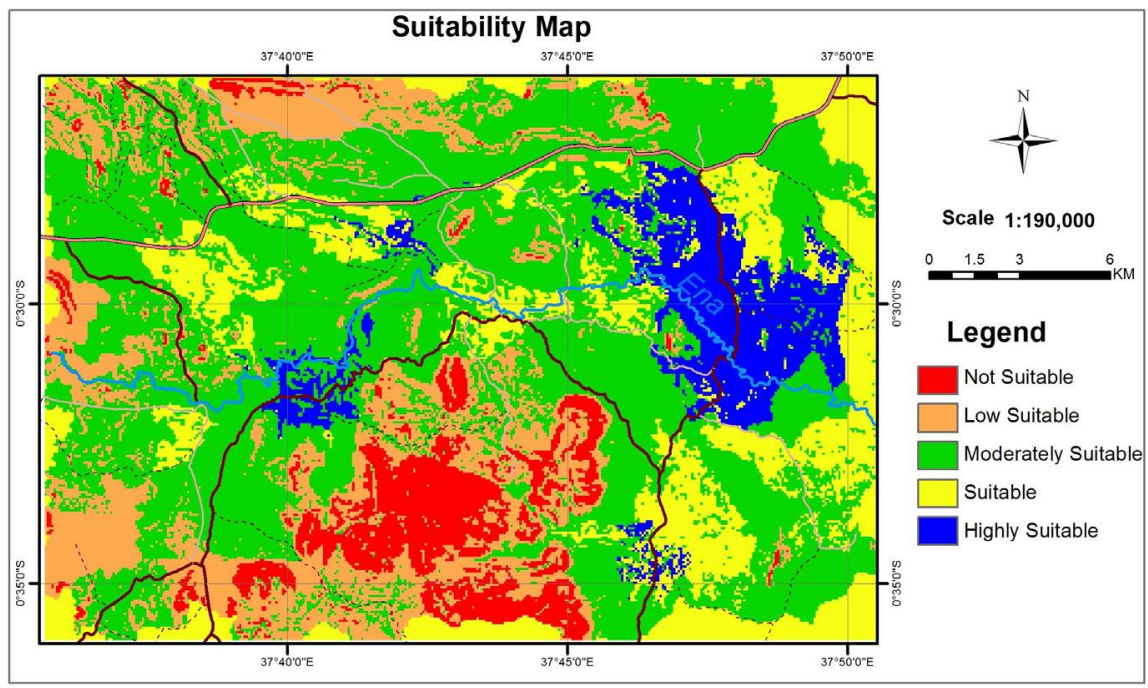

Figure 10. Suitability map.

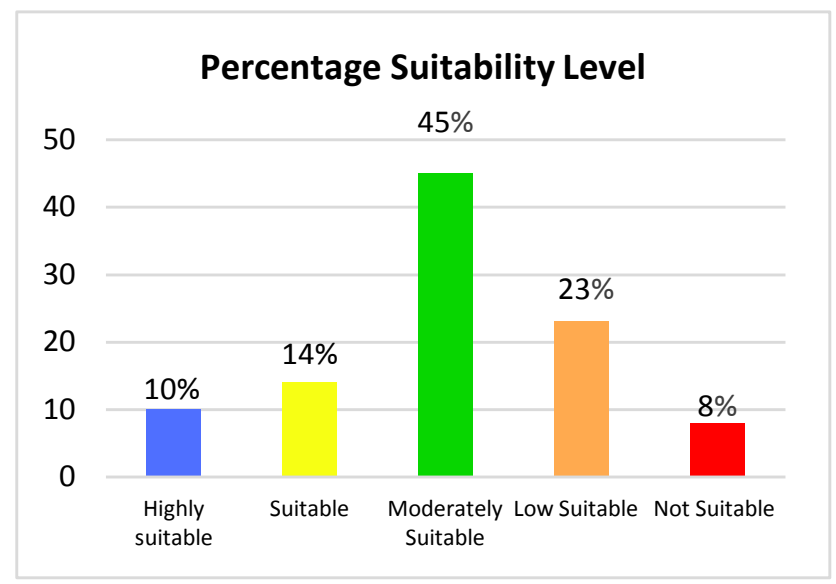

Figure 11. Summary of suitability.

$10 \%$ of the total study area showed that the area was highly suitable, $14 \%$ was suitable, $45 \%$ was moderately suitable, $23 \%$ was low suitable while $8 \%$ was not suitable for dam construction. The highly suitable classification had four possible sites with dam water capacity of 8.3 million $\mathrm{m}^{3}$ to North East, 14.9 million $\mathrm{m}^{3}$ to West, 26.9 million $\mathrm{m}^{3}$ to North West and 269.2 million $\mathrm{m}^{3}$ to North East of the study area.

The larger water capacity site was the most recommended due to its narrow formation of contour troughs and ridges allowing for various dam options. Wide contours mostly lead to a very big dam which is not economical in most cases as demonstrated in Figure 12.

The elevation within the study area ranges between 638 to $1798 \mathrm{~m}$ above sea level. After comparing the suitability map with the elevation map, the high suitability areas lies within fairly flat elevation of between 850 to $950 \mathrm{~m}$ as well as within areas of gentle slope of between $2 \%$ to $9 \%$. The suitable areas also lies 
within the drainage basin meaning the dam will be able to get water from all possible catchments within the available drainage basin. All unsuitable areas were the areas around Kiang'ombe Hills, depicting steep slopes within the area which are not suitable for dam construction.

Co-ordinates provided by Tana Water Services Board (TWSB) in their report on the development of three dams in Embu County were added on the suitability map. One of the three TWSB points fell on the suitable site of the study area as illustrated in Figure 13. Further surface area and volume analysis was done on two possible reservoirs from site A (Proposed Kamumu Dam) and Site B (Highly Suitable area). Site A had less surface area and volume than site B (see Figure 14). In reality, site $B$ would provide more water for the residents than site $\mathrm{B}$, one of the reason in which site $\mathrm{B}$ would be preferred to site $\mathrm{A}$.

On the other hand, site B is more preferred as the area is large enough such that there is enough site for weir length adjustment in case of enlargement or reduction of the reservoir size. This is not the case with the proposed site. Suitability of the proposed site is within a small area and the surroundings are low suitable areas and therefore cannot provide enough room for adjustments or alternatives if need be.

From the available documents and research on the proposed Embu dams, it is evident that GIS as well as AHP Multi-Criteria Decision Analysis was not applied during site selection. Even though the location was on a suitable site, GIS analysis integrated with AHP Multi-Criteria Decision Analysis would have resulted on a highly suitable location.

Reservoir A: Proposed Dam
Surface Area $=3,386,272.22 \mathrm{~m}$ sq.
Volume $=102,043,012.63 \mathrm{~m}$ cubed
Reservoir B: Highly Suitable Site
Surface Area $=9,168,965.44 \mathrm{~m} \mathrm{sq}$.
Volume $=269,240,464.04 \mathrm{~m}$ cubed

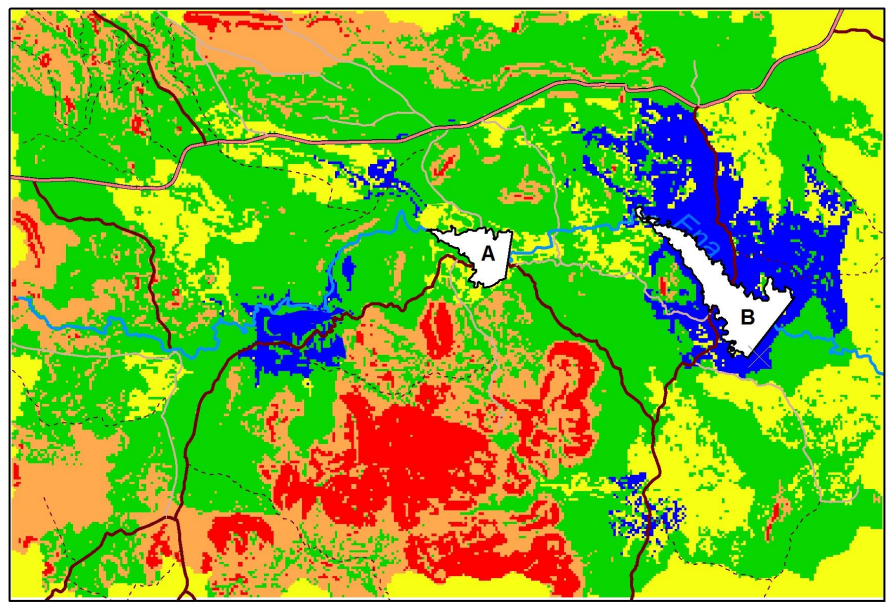

Figure 12. Contour troughs and ridges. 


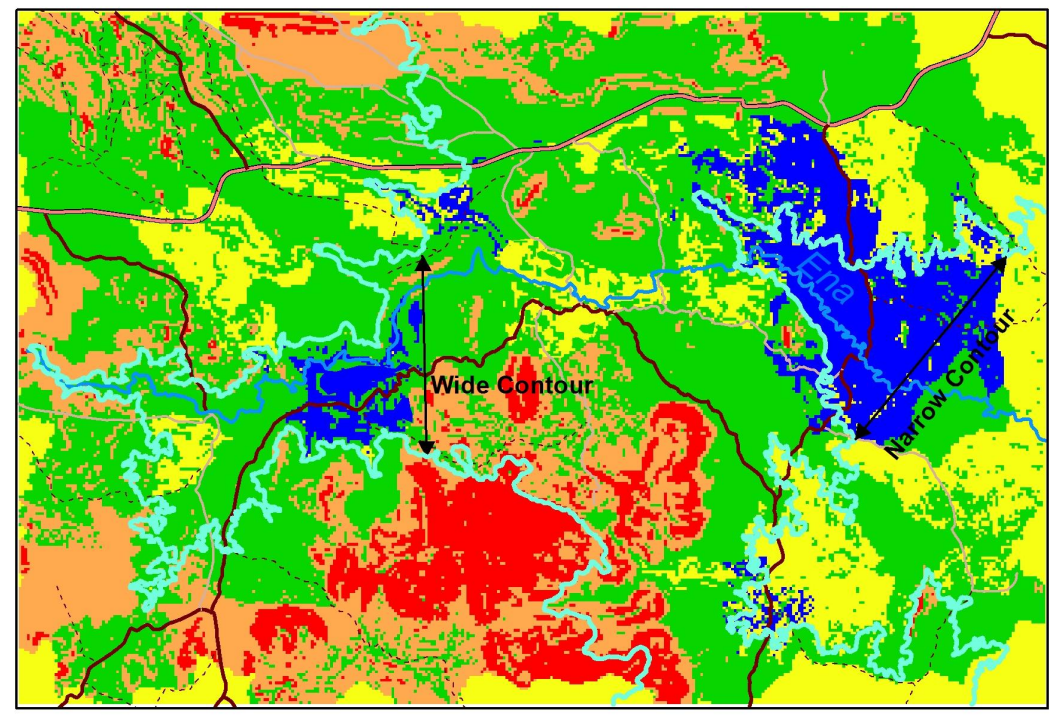

Figure 13. Proposed kamumu dam site.

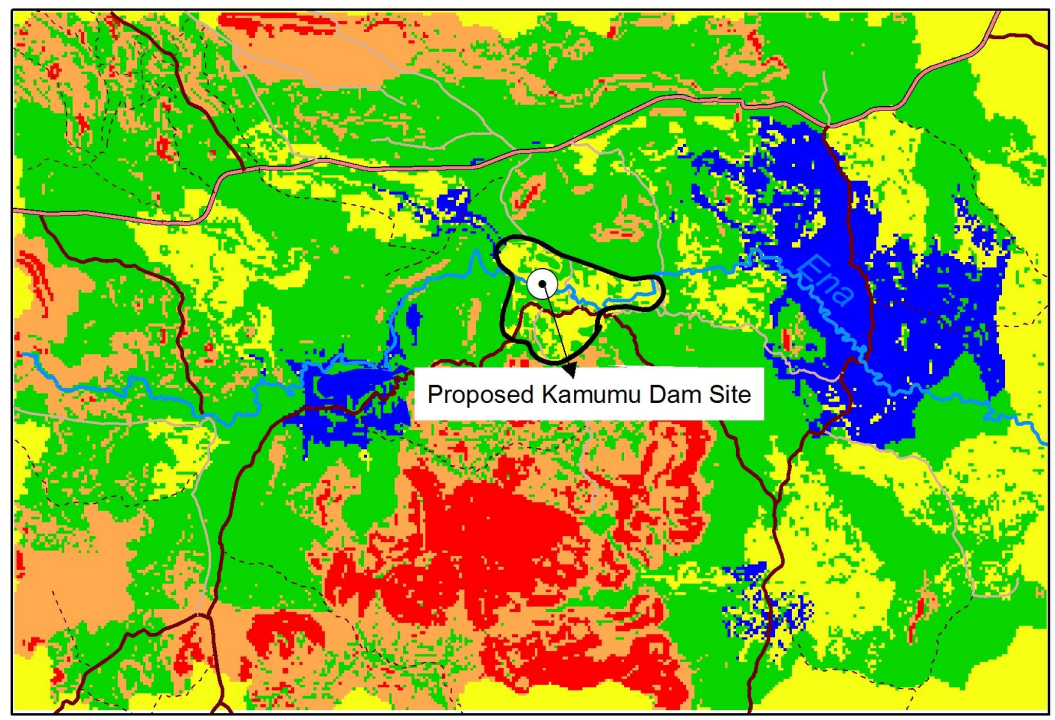

Figure 14. Possible reservoirs.

\section{Conclusions}

From the results, it is evident that integrating GIS with AHP Multi-Criteria Decision Analysis has been successful in establishing hydrological information of the region which has guided in arriving at suitable locations for dam site selection. Therefore, both are proficient and supportive decision-making tools.

The result indicates that integration of GIS with AHP Multi-Criteria Decision Analysis for a dam site selection is feasible and effective. Powered by GIS analytical capabilities and Geospatial technologies, dam site selection and planning can be done in a more effective and scientific way. This is contrary to manual methods of dam site selection using topographic maps and contours, without consideration of terrain properties which can only be discovered by GIS analysis. 
This study provides a reference for future GIS based dam site selection especially in areas where integration of GIS with Multi-Criteria Decision Analysis for a dam site selection is yet to be implemented.

\section{Conflicts of Interest}

The authors declare no conflicts of interest regarding the publication of this paper.

\section{References}

[1] Munyao, J.N. (2010) Use of Satellite Products to Assess Water Harvesting Potential in Remote Areas of Africa: A Case Study of Unguja Island. Enschede, The Netherlands.

[2] Dorfeshan, F., Heidarnejad, M. and Bo, A. (2014) Locating Suitable Sites for Construction of Underground Dams through Analytic Hierarchy Process. International Conference on Earth, Environment and Life Sciences (EELS-2014), Dubai (UAE), 23-24 December 2014, 86-90.

[3] Abushandi, E. and Alatawi, S. (2015) Dam Site Selection Using Remote Sensing Techniques and Geographical Information System to Control Flood Events in Tabuk City. Hydrology: Current Research.

[4] Beavers Advisory Committee for England. (2017) Site Selection Criteria. https://beaversinengland.com/reintroductions/release-site-selection-criteria/

[5] Ghazal, N.K. and Salman, S.R. (2015) Determining the Optimum Site of Small Dams Using Remote Sensing Techniques and GIS. International Journal of Scientific Engineering and Research (IJSER), 3, 69-73.

[6] Thanoon, H.A. and Ahmed, K.A. (2013) Hydrological Information Extraction for Dams Site Selection Using Remote Sensing Techniques and Geographical Information System. Al-Rafidain Engineering, 21, 102-114.

[7] Xu, C.-Y. (2002) Hydrologic Models. Uppsala University Department of Earth Sciences Hydrology, Uppsala.

[8] Lalhmingliana and Saha, G. (2016) Identification of Suitable Dam Site: A Survey. International Journal of Computer Engineering \& Technology (IJCET), 7, 56-64.

[9] Manugula, S.S., Veeranna, B. and Patel, S. (2015) Geo-Spatial Data Foundation for Dam Sites. International Journal of Civil Engineering and Technology (IJCIET), 6, 61-68.

[10] Dai, X. (2016) Dam Site Selection Using an Integrated Method of AHP and GIS for Decision Making Support in Bortala, Northwest China. Lund University, Lund.

[11] Emiroglu, M.E. (2008) Influences on Selection of the Type of Dam. International Journal of Science \& Technology, 3, 173-189.

[12] Lashkaripour, G. and Ghafoori, M. (2002) The Engineering Geology of the Tabarak Abad Dam. Engineering Geology, 66, 233-239. https://doi.org/10.1016/S0013-7952(02)00044-3

[13] Mati, B. (2017) Water Harvesting and Storage in Valleys Using Small Earth Dams. http://www.jkuat.ac.ke/departments/warrec/wp-content/uploads/2016/05/Water-ha rvesting-and-storage-in-Valleys-using-Earth-Dams.pdf

[14] Stephens, T. (2010) Manual on Small Earth Dams. A Guide to Siting, Design and Construction. Food and Agriculture Organization of the United Nations, Rome. 
[15] Ajin, R.S., Krishnamurthy, R.R.K., Jayaprakash, M. and Vinod, P.G. (2013) Flood Hazard Assessment of Vamanapuram River Basin, Kerala, India: An Approach Using Remote Sensing \& GIS Techniques. Advances in Applied Science Research, 4, 263-274.

[16] Ghoraba, S.M. (2015) Hydrological Modeling of the Simly Dam Watershed (Pakistan) Using GIS and SWAT Model. Alexandria Engineering Journal, 54, 583-594.

[17] Engineering Articles (2015) Selection of Dam Site. http://www.engineeringarticles.org/selection-of-dam-site/

[18] Tim, U.S. and Mallavaram, S. (2003) Application of GIS Technology in Watershed-Based Management and Decision Making. Watershed Update, 1, 1-6.

[19] Hosseinzadeh, S.R. (2011) Drainage Network Analysis, Comparis of Digital Elevation Model (DEM) from ASTER with High Resolution Satellite Image and Areal Photographs. International Journal of Environmental Science and Development, 2, 194-198.

[20] Triantaphyllou, E. (2000) Multi-Criteria Decision Making Methods: A Comparative Study. Springer Science + Business Media, Dordrecht.

[21] Saaty, T.L. (2008) Decision Making with the Analytic Hierarchy Process. International Journal of Services Sciences, 1, 83-98. https://doi.org/10.1504/IJSSCI.2008.017590

[22] Al-shabeeb, A.R. (2016) The Use of AHP within GIS in Selecting Potential Sites for Water Harvesting Sites in the Azraq Basin-Jordan. Journal of Geographic Information System, 8, 73-88.

[23] MoALF (2016) Climate Risk Profile for Embu. Kenya County Climate Risk Profile Series. The Kenya Ministry of Agriculture, Livestock and Fisheries (MoALF), Nairobi, International Centre for Tropical Agriculture (CIAt), Nairobi.

[24] Bear, L. (1952) A Geological Reconnaissance of the Area South-East of Embu.

[25] Marinos, P.G., Koukis, G., Tsiambaos, G. and Stournaras, G. (1997) Engineering Geology and the Environment. Volume 2, A.A. Balkema, Rotterdam.

[26] ILRI (2017) GIS Services. http://192.156.137.110/gis/search.asp?tbCountry=\&tbCoverage=\&tbLayer=\&tbFeat ure $=\&$ tbTheme $=$ \&opCoverage $=$ \&opCountry $=$ \&opLayer $=$ \&opTheme $=$ \&opBoolean $=\&$ display $=$ Brief\&rgone $=71 \&$ rgtwo $=80$

[27] BPMS (2017) Multi-Criteria Decision Making Using the Analytic Hierarchy Process. http://bpmsg.com/academic/ahp.php

[28] Bunruamkaew, K. (2012) How to Do AHP Analysis in Excel. University of Tsukuba, Tsukuba.

[29] Djokic, D. (2012) Hydrologic and Hydraulic Modeling with ArcGIS. ESRI, San Diego.

[30] Government of Western Australia (2014) Dam Construction and Operation in Rural Areas. Water Quality Protection Note 53 Rural Dams, 1-27.

[31] Saaty, T.L. (1977) A Scaling Method for Priorities in Hierarchical Structures. Journal of Mathematical Psychology, 15, 234-281.

https://doi.org/10.1016/0022-2496(77)90033-5

[32] Esri (2017) Understanding Overlay Analysis. http://desktop.arcgis.com/en/arcmap/10.3/tools/spatial-analyst-toolbox/understand ing-overlay-analysis.htm

[33] Ghafoori, M., Lashkaripour, G.R. and Azali, S.T. (2011) Investigation of the Geo- 
logical and Geotechnical Characteristics of Daroongar Dam, Northeast Iran. Geotechnical and Geological Engineering, 29, 961-975.

https://doi.org/10.1007/s10706-011-9429-6

[34] Queensland (2017) Environmental Factors That Influence Site Selection. https://www.business.qld.gov.au/industries/farms-fishing-forestry/fisheries/aquacul ture/site-selection-production/selecting-site-land/environmental-factors

[35] Pimentel, D. and Burgess, M. (2013) Soil Erosion Threatens Food Production. Agriculture, 3, 443-463. https://doi.org/10.3390/agriculture3030443 